\title{
Erythema as a Visual Surrogate Marker of Glucagonoma
}

\author{
Nobuaki Ochi ${ }^{1}$, Tatsuyuki Kawahara ${ }^{2}$, Hiromichi Yamane ${ }^{1}$ and Nagio Takigawa ${ }^{1}$
}

Key words: glucagonoma, necrolytic migratory erythema, paraneoplastic syndrome

(Intern Med 57: 2283-2284, 2018)

(DOI: 10.2169/internalmedicine.0100-17)
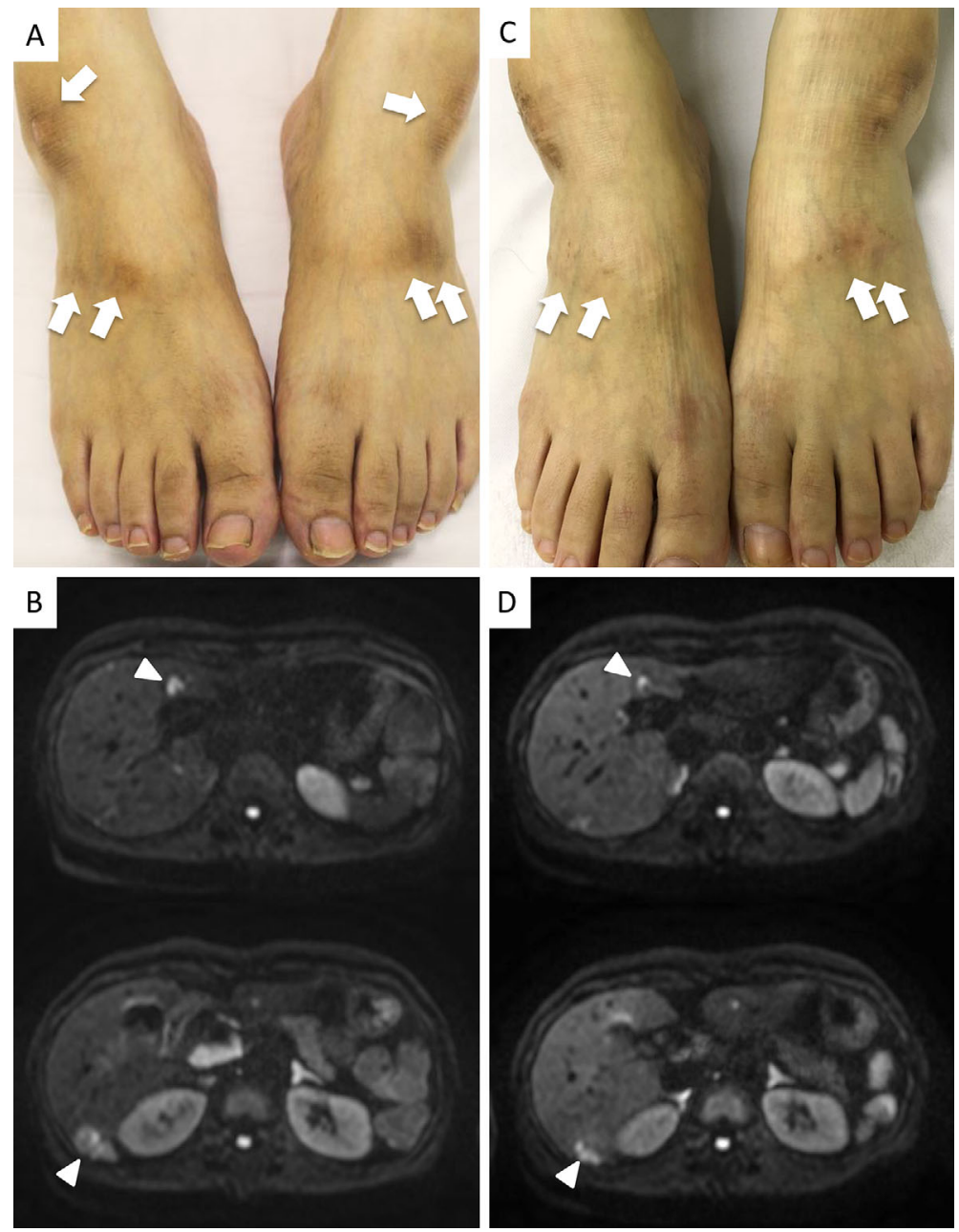

Picture.

A 61-year-old female presented with progressive erythema on her foot (Picture A). She had previously undergone surgical resection of a pancreatic neuroendocrine tumor with a Ki-67 index of 15\%, octreotide treatment, chemotherapy, and transarterial embolization over the previous eight years.
Metastases to the liver were identified on magnetic resonance imaging (Picture B). We initially administered sunitinib (37.5 mg per day) in an effort to inhibit the vascular endothelial growth factor- and platelet-derived growth factormediated receptor signaling (1). Four months later, the

${ }^{1}$ Department of General Internal Medicine 4, Kawasaki Medical School, Japan and ${ }^{2}$ Clinical Education and Training Center, Kawasaki General Medical Center, Kawasaki Medical School, Japan

Received: August 21, 2017; Accepted: January 14, 2018; Advance Publication by J-STAGE: March 9, 2018

Correspondence to Dr. Nagio Takigawa, ntakigaw@gmail.com 
erythema was resolved (Picture C). Magnetic resonance imaging revealed that the liver metastases responded to this treatment (Picture D). The serum glucagon level (initially $803 \mathrm{pg} / \mathrm{mL}$; reference level $71-174 \mathrm{pg} / \mathrm{mL}$ ) fell to $425 \mathrm{pg} /$ $\mathrm{mL}$. We thought that the successful treatment of glucagonoma by sunitinib improved the necrolytic migratory erythema. Because necrolytic migratory erythema is an important paraneoplastic syndrome associated with glucagonoma (2), physicians should be aware of this symptom.

The authors state that they have no Conflict of Interest (COI).

\section{References}

1. Raymond E, Dahan L, Raoul JL, et al. Sunitinib malate for the treatment of pancreatic neuroendocrine tumors. $\mathrm{N}$ Engl J Med 364: 501-513, 2011.

2. John AM, Schwartz RA. Glucagonoma syndrome: a review and update on treatment. J Eur Acad Dermatol Venereol 30: 20162022, 2016.

The Internal Medicine is an Open Access article distributed under the Creative Commons Attribution-NonCommercial-NoDerivatives 4.0 International License. To view the details of this license, please visit (https://creativecommons.org/licenses/ by-nc-nd/4.0/).

(C) 2018 The Japanese Society of Internal Medicine Intern Med 57: 2283-2284, 2018 